\title{
Analysis of seismic parameters for the earthquake vulnerability assessment of Nusretiye (Tophane) Clock Tower
}

\author{
Özden Saygılı* (iD, Gulten Polat ${ }^{a}$ \\ aDepartment of Civil Engineering, Faculty of Engineering, University of Yeditepe, i̇stanbul, Turkey. E-mail: ozden.saygili@yeditepe.edu.tr, \\ gulten.polat@yeditepe.edu.tr
}

*Corresponding author

https://doi.org/10.1590/1679-78256361

\begin{abstract}
In this study, we have investigated the impacts of hazardous earthquakes on the Nusretiye Clock Tower which is one of the historical heritages located in the city of istanbul. We analyzed the seismicity of the region and performed nonlinear dynamic analyses under real and artificial ground motion data set to contribute to protecting this cultural heritage and its transmission to future generations. To calculate the seismicity parameters (b-values, a- values, Magnitude of completeness) of the region, we have collected a current catalogue in the Marmara region whose coordinate range is $26^{\circ}-31^{\circ} \mathrm{E}$ longitudes and $40^{\circ}-42^{\circ} \mathrm{N}$ latitudes. The current catalogue is constructed from 15 April 1905 to 31 December 2020. A complete set of 29223 earthquakes of Md $\geq 1$ obtained from Bogazici University, Kandilli Observatory and Earthquake Research Institute, Regional Earthquake-Tsunami Monitoring Center. In the light of the nonlinear dynamic analysis results, masonry tower is significantly vulnerable to suffer strong damage or collapse in an earthquake with a return period of 2475 years.
\end{abstract}

\section{Keywords}

Masonry; clock tower; historical; seismic behavior; İstanbul; Tophane

\section{Graphical abstract}
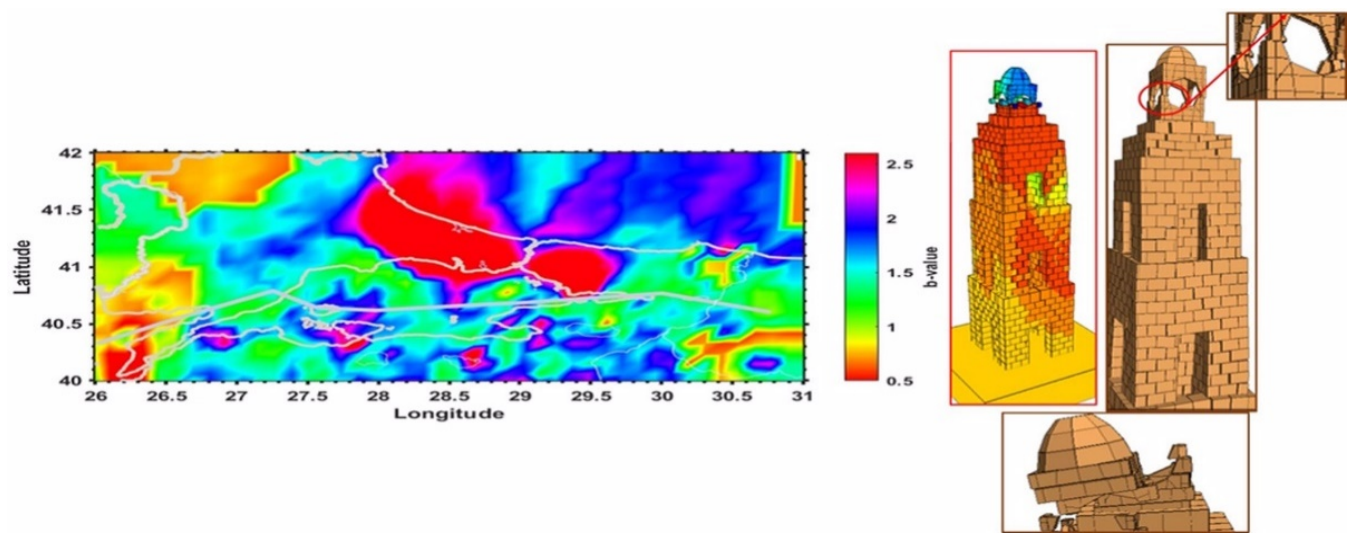


\section{INTRODUCTION}

Investigation of seismic behaviour of historical structures represents an actual and challenging issue especially in in earthquake prone countries. Masonry clock towers are one of the most important architectural heritage that vulnerable to seismic motion. Construction of clock towers emerged in Europe at the beginning of the 14th century and first clock tower was built in the Ottoman lands in the 16th century. After the 18th century it became widespread in Anatolia and all Ottoman borders. In time, clock towers, which stand out with their functionality as well as symbolic, had become the centre of city life. They were generally were built in in the main squares of the cities where the settlements are located. In Anatolia, first clock tower was built in Safranbolu in 1797. Clock towers within the borders of Anatolia in the 19th century generally have a plan scheme with a square or polygonal body. They are made of cut stone material. The heights of those built as a single independent structure are between 25 and 32 meters. Those on a building or castle were made shorter, between 9 and 15 meters. In this case study Nusretiye clock tower located in the historical district of Tophane to the south of the Bosphorus, i̇stanbul is selected (Figure 1). Nusretiye Clock Tower is considered as the earliest clock tower of Istanbul. To the south of the Nusretiye Mosque, the masonry clock tower is situated. From the inscription on the ground floor window on the south facade of the building, it is understood that the masonry building was constructed between 1848 and 1849 (Acun, 1994). Considering geometric layout of the tower, it is gradually narrows upwards with $4.50 \mathrm{~m} \times 4.50 \mathrm{~m}$ square cross-section of ground floor. The building was built in a masonry system with four floors together with the clock section at the top. The height of the tower is measured as 14.75 meters in its current form (Gürsu, 2016). The building has four architectural piers each located at the corners without being dependent on the facade. The doors opening between the columns in the Doric style on each facade are high and arched. Today, the access to the upper floors of the tower is provided by circular spaces opening to the corners of the floor slabs. For the exit, there are two rusted iron stairs mounted on the wall on the first and second floors. The stone clock tower had suffered a fire in 1913. The inspection to Nusretiye clock tower showed that it is not in good condition for the most part. The masonry building still have the traces of the fire it passed through in 1913. Furthermore, it has not been repaired and clock dials and mechanisms are not available. The deterioration of the additional reinforced concrete floors between floors damaged the building. The cut stone masonry building generally consists of the same type of stones. These are described as fossil Sparitic limestone and it has been observed that stones with a high amount of clay deteriorate more than stones with a low amount of clay (iBB, 2011). In addition, some parts have cracks on the wall which could jeopardize the clock tower's stability.

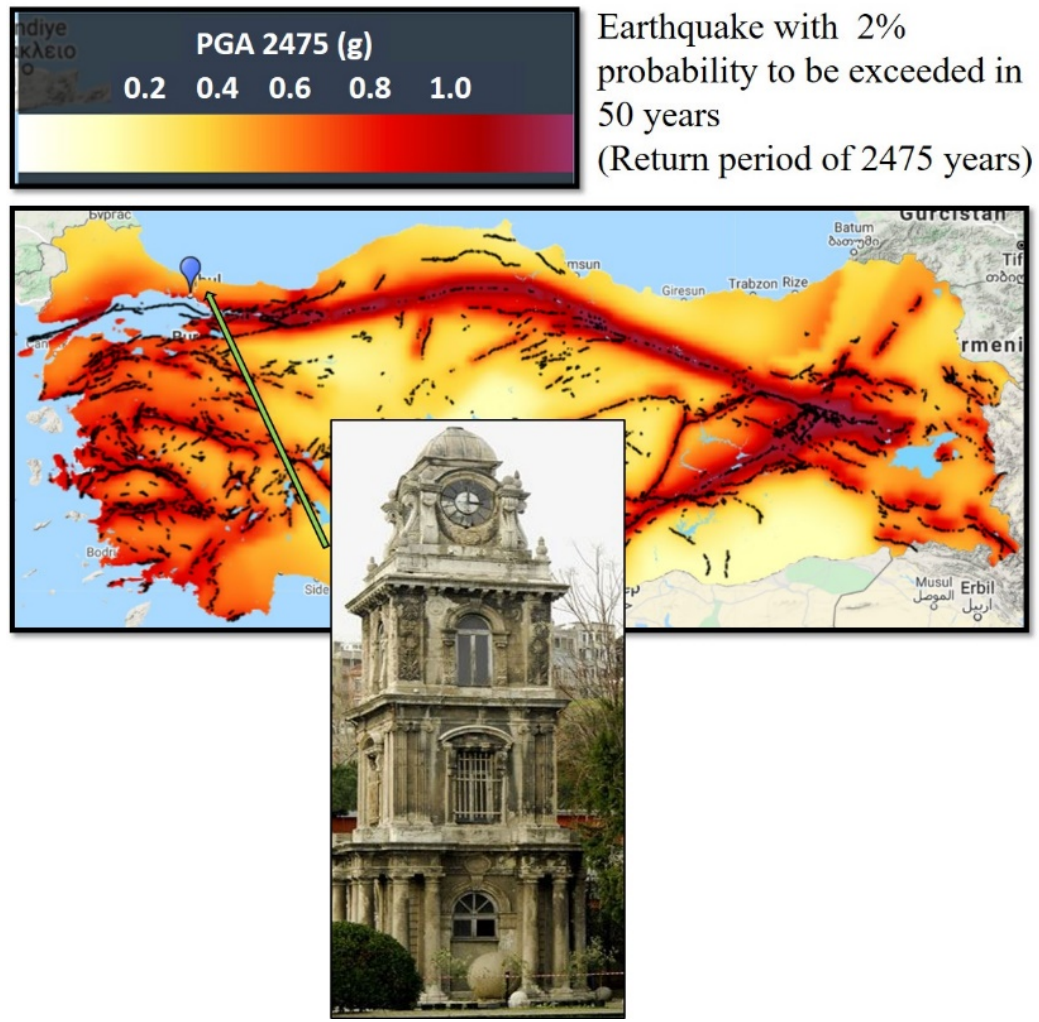

Figure 1 Turkey earthquake risk map adopted from AFAD and view of Nusretiye (Tophane) Clock Tower (AFAD, 2020). 
Nusretiye (Tophane) Clock Tower, with its unique location, is an important cultural heritage that should be passed on to future generations. In this study seismic performance of the Nusretiye Clock Tower is investigated through discrete element method (DEM). This approach provides detailed mechanical and geometrical characteristics to capture the seismic response of the masonry structures. In the framework of the computations, 3DEC software (Itasca, 2016) was used. The 3DEC allows to represent the stone blocks by a rigid block interacting through non-linear joints. Rigid blocks with finite displacement and rotation were created that can recognize and update automatically the contacts during the dynamic loading. For each rigid block, interfaces are represented by contacts with nonlinear mechanical properties. Nonlinear dynamic analyses were performed under real and artificial ground motion data set. It is intended that the interpretation of the nonlinear dynamic analysis results lead to contribute to protecting the cultural heritage of Nusretiye Clock Tower and its transmission to future generations. In addition, the spatial variations of values were studied the means of earthquakes with a magnitude completeness of 2.8 in the Marmara region whose coordinate range is $26^{\circ}-31^{\circ} \mathrm{E}$ longitudes and $40^{\circ}-42^{\circ} \mathrm{N}$ latitudes, from 15 April 1905 to 31 December 2020. Considering the findings provide to be established the correlation between the crustal areas with low b-values and the locations of the strongest earthquakes in the investigated region. The produced map of the b-value suggests that it may be helpful for estimating the location, depth, and maximal magnitude of the probable strong earthquakes in seismically active regions. Therefore, findings based on such a study can be used to assess seismic risks.

\section{SEISMICITY AND TECTONIC SETTING}

The Anatolian plate situated in Turkey is sited at the collisional boundary between the Arabian plate in the south and Eurasian in the north. In the western part of the Turkey, the Anatolian plate is governed by the African plate and the Aegean Sea plate. This plate comprised of a complex and comparatively active tectonic system with respect to the surrounding plates. (Figure 2). Due to these interactions among the plates, the Anatolian plate is moving westward, relative to the Eurasian Plate, in eastern Turkey at approximately $40 \mathrm{~mm} / \mathrm{yr}$ (Pichon et al., 1995), but begins moving south westerly in western Turkey (Jackson, 1994). As a result of these intensive compressional forces against the Anatolian plate, East Anatolian Fault (EAF) and North Anatolian Fault (NAF) (see Figure 2) were developed in the plate. The NAF is composed of two strands namely, southern and the northern NAF strand. The northern strand accommodates much of the deformation of the NAF below the Marmara Sea. Since 1912, the fault was ruptured progressively by a number of large and devastating earthquakes beginning with eastern Anatolia and moving to the west towards Istanbul. Due to the 1999 Düzce and Kocaeli earthquakes (Figure 3a), the NAF experienced about 200 $\mathrm{km}$ rupture. Due to this rupture the fault was divided into a several segments in the west. Submerged under the Marmara Sea, to the west of the 1999 Kocaeli earthquake rupture zone, is the northern strand of the NAF (Barka, 1992; Şengör, 2005). Since the 1999 Kocaeli earthquake, comprehensive studies have been carried out for Istanbul against earthquake hazards by investigating the seismic activity below the Sea of Marmara along the part of the NAF. The worldwide oldest seismic loading database analysis of the city show that the İstanbul has been experienced a moderate intensity of seismic shaking in fifty years and more severe one about every three hundred years (Ambraseys and Finkel, 1991). In 2002, the Istanbul Metropolitan Municipality (IMM) and the Japan International Cooperation Agency carried out a study titled "The Study on A Disaster Prevention/Mitigation Basic Plan in Istanbul including Seismic Micro zonation in the Republic of Turkey" (JICA, 2002). In addition, in 2002 for The Red Crescent and The Red Cross, Kandilli Observatory and Earthquake Research Institute (KOERI) conducted a study of Earthquake Risk Assessment for Istanbul Metropolitan Area (BU-ARC, 2002). In 2009, IMM and KOERI has performed a study titled "Updating of Probable Earthquake Losses for Istanbul" (IMM, 2009). Considering the average recurrence time about 250 years northern strand of the NAF is presently in the homestretch of its seismic period (Parsons, 2004; Bohnhoff et al., 2016). It is believed that an earthquake with a magnitude of Mw 7.0 threatens the city of Istanbul (Wollin et al. 2019). Seismicity of the select region is given in Figure 3a which covers the period between 1900 and 2020. Figure $3 \mathrm{~b}$ indicates only earthquakes with a magnitude of $\mathrm{M} 4.5$ and greater from 1900 to 2020 . In addition, seismic excitations in terms of maximum focal depth that reaches $100 \mathrm{~km}$ depicted in Figure $3 \mathrm{a}, \mathrm{b}$. According to these maps, the selected region is considered to show a seismic gap for an earthquake potential 4.5 of $M$ up to 7.4. In addition to these earthquakes, Turkey and Environment Historical Earthquake Catalogue between the 16th and 20th centuries indicated four earthquakes with 9 or higher intensity occurred in Istanbul and its surroundings (Polat and Sayglı 2020). Since the İstanbul faces a significant earthquake with a moment magnitude above 7.0, it is worthwhile to understand the seismic behaviour of historical Nusretiye (Tophane) Clock Tower. 


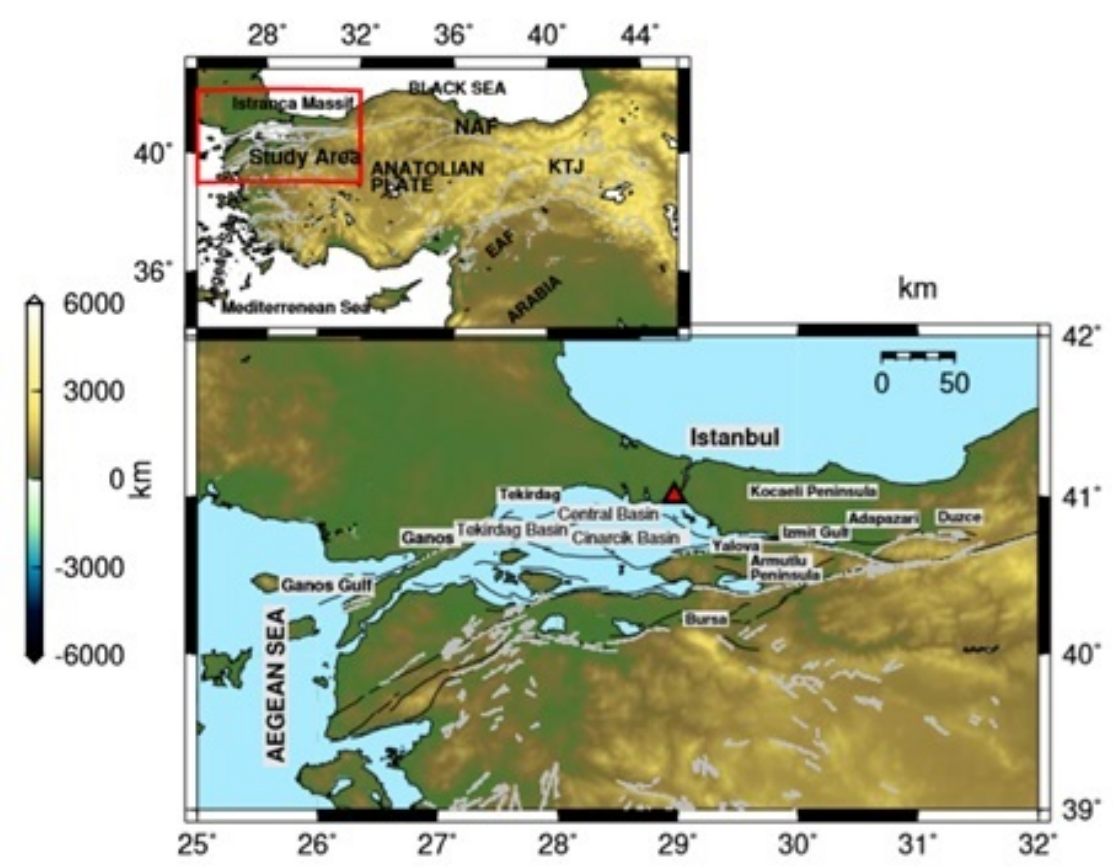

Figure 2 The tectonic map of Marmara region (dot gray faults from Saroglu et al. (1987), thick black faults from Armijo et al. (1999)). Inset: The location of the study area within Turkey is marked red. (KTJ) Karlıova Triple Junction; (EAF) East Anatolian Fault and (NAF) North Anatolian Fault
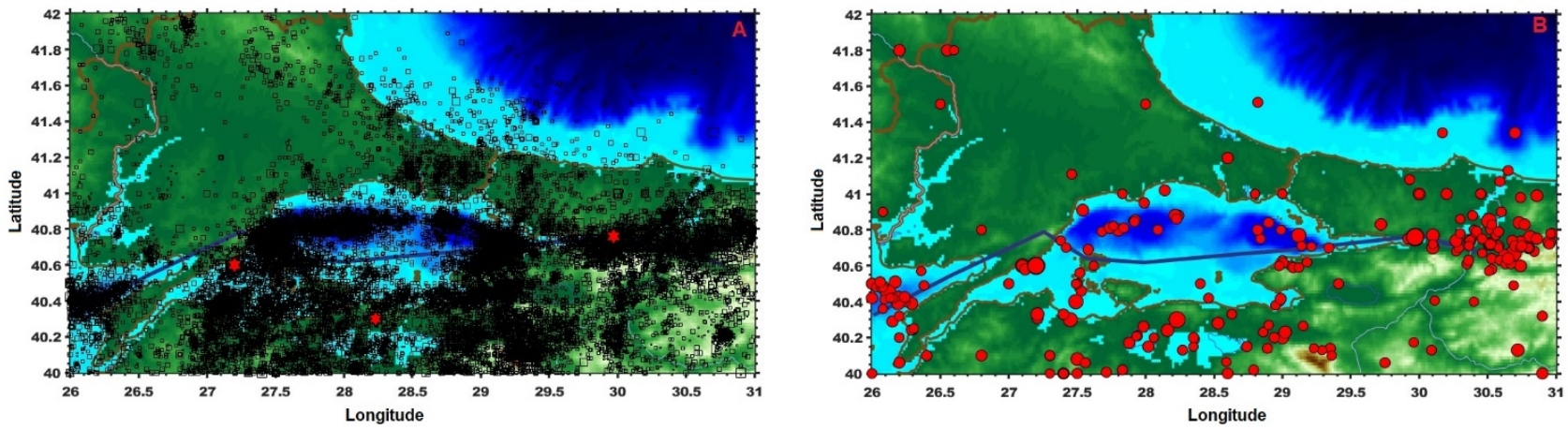

Figure 3 (A) Earthquakes with a magnitude of Md 1 and greater from 1900 to 2020. Red stars show earthquakes with a magnitude of Mw 7 and greater. (B) Red circles indicate earthquakes with a magnitude of M 4.5 and greater from 1900 to 2020.

In the scope of this study, the frequency-magnitude distribution was investigated in the Marmara region whose coordinate range is $26^{\circ}-31^{\circ} \mathrm{E}$ longitudes and $40^{\circ}-42^{\circ} \mathrm{N}$ latitudes. From 15 April 1905 to 31 December 2020, a complete set of 29223 earthquakes of Md $\geq 1$ was taken from Bogazici University, Kandilli Observatory and Earthquake Research Institute, Regional Earthquake-Tsunami Monitoring Center (KOERI) (Figure 3a). The earthquakes occurred in the region between the years of 1970 and 2020 were particularly assessed within the scope of the study because the data set prior to 1970 was found insufficient due to lack of seismic records. The current earthquake catalogue data has been checked in two aspects; the time dependent variation and compliance for the whole region. Before analysing the constructed catalogue, declustering analysis was applied to the raw catalogue to eliminate artificial (unnatural) events relating to artificial quarry blasts and mine blasts from real (natural) seismic events. For the declustering process, Reasenberg and Gruenthal algorithm as a part of Stefan Wiemer's ZMAP package (Wiemer, 2001) was used. In order to ensure the data set integrity, the current data set was converted to local magnitude by using a formula used in this conversion which is as provided hereinafter; $\mathrm{ML}=\left(0.9897^{*} \mathrm{Md}\right)+0.0978(\mathrm{R} 2=0.8955$; Cohesion coefficient) (Kalafat 2016). To calculate seismic parameters (Magnitude of Completeness (Mc), b-value and a-value) of the study area, the independent events was analyzed by using ZMAP tool (Wiemer, 2001). The earthquakes occurred in the region between the years of 1970 and 2020 were assessed within the scope of the study. Number of the earthquake within the selected period was 23376 and magnitude range $=1.09-7.4$ and depth $=0-50 \mathrm{~km}$. The final catalog indicates that most of earthquakes in the depth range between 5 and $10 \mathrm{~km}$ occurred in the Marmara region whose coordinate range is $27^{\circ}-29.5^{\circ} \mathrm{E}$ longitudes and $40^{\circ}-41^{\circ} \mathrm{N}$ 
latitudes. The number of seismic events was gradually increased in the year of range between 2000 and 2020 (Figure 4). The number of earthquakes as a function of time between 2007 and 2009 is smaller than the 2010-2018 period. During this period (2018-2020), the seismic activity decreased. Figure 5 shows the histogram of magnitude distribution for the data set of the region. The magnitudes of most earthquakes were from 2 to 3.3 , and a maximum was observed at $M=7.4$.

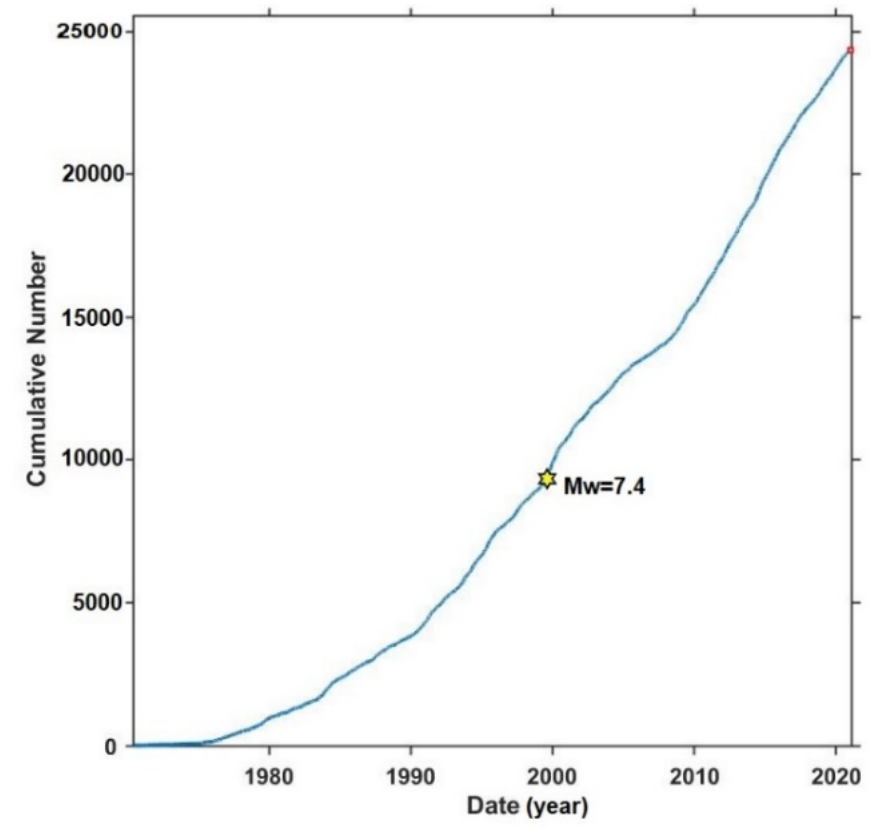

Figure 4 Cumulative number of earthquakes from 1970 to 2020.

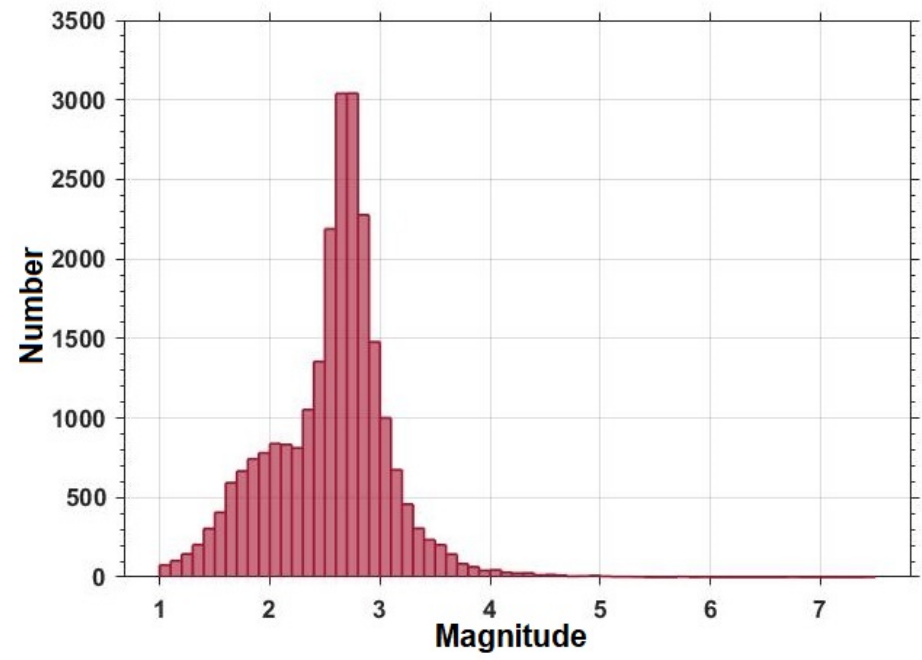

Figure 5 Magnitude - occurrence number of histogram of events used in the present study.

To define empirically relations in seismic hazard analysis, the Gutenberg-Richter relation (Gutenberg and Richter, 1944) and the maximum likelihood method (Aki, 1965) are widely used. To define the frequency of occurrence of earthquakes as a function of magnitude, this equation: $\log 10 \mathrm{~N}=\mathrm{a}-\mathrm{bM}$ is used. In this equation, $\mathrm{N}$ denotes the cumulative number of earthquakes with magnitude greater than $M$ where a-value and $b$-value are assumed to be constants. The b-value in the Gutenberg-Richter relation is unitless to measure of relative frequency of small and large earthquakes. The $b$-value gives information about size distribution for the relative abundance of the strong to the weak earthquakes. When the $b$-value is considered to be related to tectonic structure of the study area, the a-value is associated with the seismic activity of the region. The b-value is generally regarded as one of the important parameters representing the nature of the occurrence of earthquakes. Particularly, the b-value is used to characterize the state of stress in the crust. Therefore, the parameters give valuable information about the study area's seismic activity as well as the tectonic regime of the investigated area. The Mc generally showed unstable values from 1970 to 2020 . It suddenly decreased to 1.9 in the ending of the 2013 (Figure 6). 


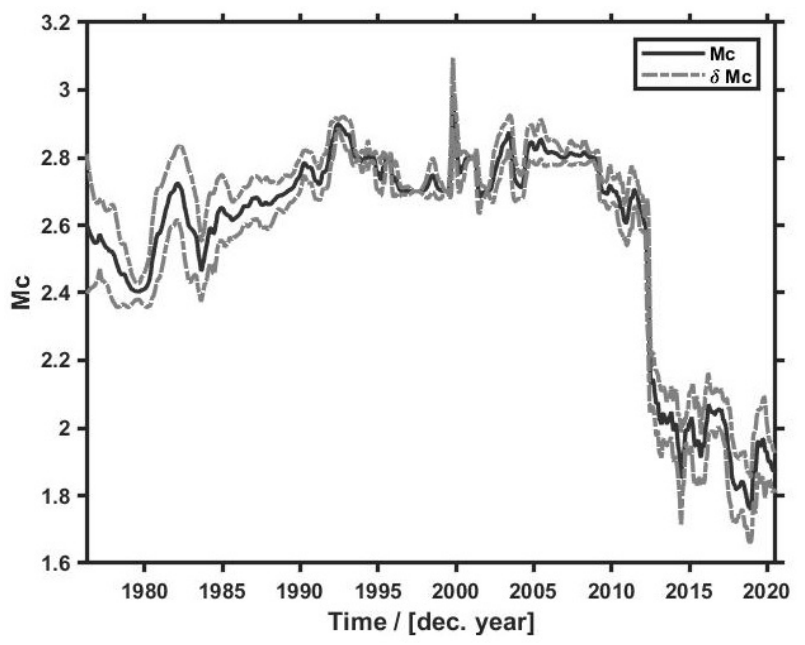

Figure 6 Magnitude completeness (Mc) versus time.

A sharp decreasing started around 2013 parallel to increasing of number of stations and number of recorded small earthquakes. A spatial grid of points with a distance of $0.05^{\circ}$ was assumed. With the Mc value assumed to be 2.8 , the $b$-value was then calculated as $1.48 \pm 0.02$. The spatial distribution of b-value for the Marmara region is shown in Figure 7 . As seen in Figure 7, the b-values of seismicity for this region are not homogeneous. Many factors can cause perturbations of the $b$ value. Some of the factors including crustal heterogeneity (Mogi, 1962) and an increase in the thermal gradient cause a serious increase in b-value (Warren and Latham, 1970; Wiens and Gilbert, 1996). On the other hand, the factors consist of an increase in applied shear stress (Scholz, 1968; Urbancic et al., 1992), or an increase in effective stress (Wyss, 1973) are responsible for a significant decrease in b-value. In addition to these, tectonic environment, data quality and completeness, magnitude type, depth and other geophysical and geotectonic characteristic influence variations in b-value. We calculated b-values for different ranges of depths: $0-5 \mathrm{~km}, 5.1-15$ and $15.1-50 \mathrm{~km}$. The b-values for each depth are 1.44 $\pm 0.02,1.34 \pm 0.02$ and $1.5 \pm 0.04$, respectively. This suggests that the b value varies with depth. However, Mc-values in the different ranges of depths varied from 2.7 and 2.8. For the depths of 0-5 km and 15.1-50 km, Mc-value is 2.7. Additionally, to find out variations in b-value with magnitude, $b$-values and Mc are calculated in different ranges of magnitudes:1.09-3, 3.1-4.5 and 4.51-5.5. In the magnitude range between 1.09 and 5.5, Mc values strongly increased. The Mc for each magnitude range of 1.09-3, 3.1-4.5, 4.51-5.5 is 2.7, 3.2 and 4.7, respectively. However, b-value in the magnitude range of 3.1-4.5 is smaller than magnitude range of 1.09 and 3. In the scope of the study, the maximum difference in b-value $(\Delta b)$ is found to be 0.15 in the magnitude range of 4.51 and 5.5 . The maximum differences in b-values $(\Delta b)$ are found to be 0.17 for the whole Earth. This suggests that the calculated b-values for the region seems reliable and consistent. Considering all findings indicated that the $b$-value that obtained for the study area was larger than typical b value for the whole Earth which is $1.06 \pm 0.02$ (El-Isa, 2013). The b-value of nearly 2.5 for the entire city of Istanbul and the Istranca massif (Figure 7) represents a largest value for this region value. This is probably relating to crustal heterogeneity of the region. The b-value of slightly greater than 0.5 for Ganos, the Ganos Gulf and the surrounding area represents a smaller value for this region. In addition, the b-values for the southern part of the Marmara Sea, the city of Balikesir and the city of Bursa varied from 1 to smaller than 2 . The b-values varied from 1 to 1.5 are observed in the kocaeli Peninsula, the cities of Adapazarı, Düzce and Yalova, the Izmit Gulf and the Armutlu Peninsula.

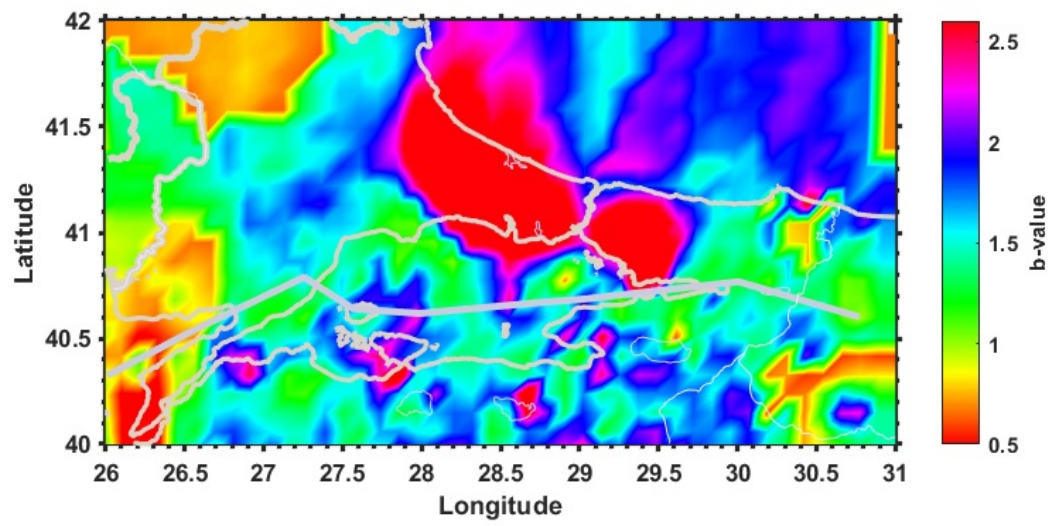

Figure 7 The spatial distribution of b-value for the Marmara region. 


\section{GROUND MOTION DATA SET}

There are three ways of accelerograms use for engineering design and performance evaluation as simulated synthetic records obtained from seismological models, artificial records compatible with target spectrum and scaled or unscaled real earthquake records. Generally simulated seismic excitation would be obtained by three different techniques ie. Stochastic simulation, composite source modelling and empirical Green's function (EGF) modelling method. Among these methods, stochastic simulation approach is based on empirical methods for simulation of loading generally by fitting the Gaussian white noise procedures in the frequency domain to generate high and low frequency strong ground motions (Boore, 2003; Motazedian and Atkinson, 2005; Yamamoto and Baker, 2013). Generally this methodology requires information for the region of inelastic attenuation, local site amplification, geometrical decay rates and source spectral amplitude to simulate the motion. The composite source modelling or hybrid technique requires detailed source information in terms of stress drop parameter, fault plane solution and velocity $Q$ structure of the region to generate the broadband strong ground motion (Graves and Pitarka, 2004; Ameri et al., 2009; Frankel, 2009; Yu et al., 1995). It is not always easy to get these parameters for a site of interest. The EGF modelling technique is based on a limited fault which is then separate into sub-faults to simulate the ground motion (Kamae and Irikura, 1992; Irikura et al., 1997).

The EGF technique requires recorded accelerogram of main shock observed in the area of the modelled seismic excitation however semi-empirical techniques do not use the data recorded after the strongest shaking. In this method, these data are replaced with Green's function (Vanmarcke and Gasparini, 1977; Joshi and Sandeep, 2014). The second way of source of accelerogram is generation of artificial ground motion (AGM) using a target spectrum. Deterministic Wavelet-based and stochastic method are the common techniques for generation of spectrum compatible accelerogram. The deterministic approach based on a principle of superposition of separate consonant motion leads to a non-stationary motion. The Wavelet-based approach adjust the recorded signals to compatible response ground motions. The stochastic method based on the evaluation of ground motion as a Gaussian procedure, and for the first time it was introduced by Vanmarcke and Gasparini (1977) who represented the relationship between the power density function and a response spectrum. This research leads to a number of studies and power spectral density adjustment algorithmic rule to produce accelerogram in accordant with target spectrum (Suárez and Montejo, 2005; Hancock et al., 2006; Giaralis and Spanos, 2009; Sarkar et al., 2016). In this study, eight artificial ground motion were created compatible with target spectrum using stochastic approach. Target spectrum of the region is created according to the Turkish Building Seismic Code 2018 (TBSC, 2018). TBSC 2018 provides an envelope of spectra that compatible with expected earthquakes for the selected coordinates in Turkey regarding the effect of a number of seismic sources at the same time. TBSC 2018 allows to establish a target spectrum for four different ground motion level. In this study to simulate the largest earthquake ground motion, a target spectrum is created for ground motion level 2 corresponding to $2 \%$ probability of exceedance in 50 years Return period of this ground shaking is about 2475 years.

It is possible to consider the generation of an artificial ground motion consistent with the target spectrum as an optimization technique in which the response spectrum is to be matched as near as possible to the target spectrum by using the Fourier transform to adapt its frequency content. Firstly, power spectral density function was calculated from the smoothed response spectrum. Following the power spectral density function, sinus waves with random phase angles and amplitudes were generated. When the sinus waves were generated they were summed and windowing function was applied to modulate the signals in the time domain. A comparison of the generated artificial ground motion and target spectrum is exhibited in Figure 8.

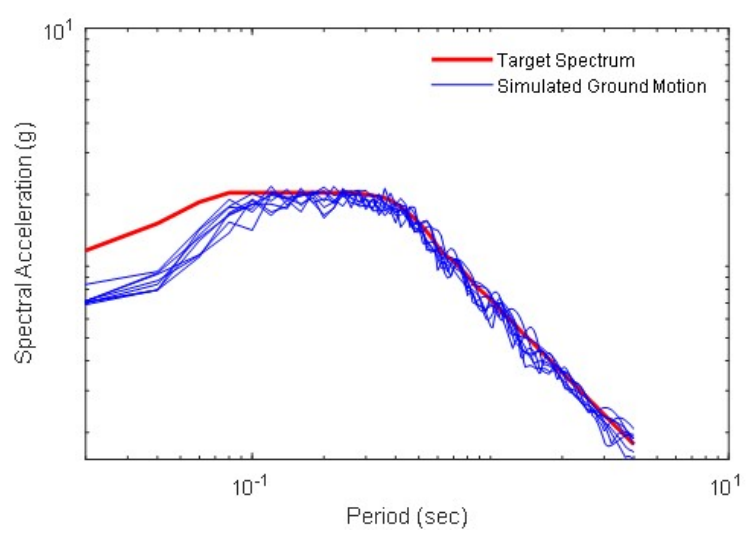

Figure 8 Comparison of generated artificial ground motion and target spectrum. 
In addition to the AGM, natural accelegrams were also used as an input in response history analysis. When selecting the real ground motion, the aim was to match the target spectrum with a specified period range that represent the site hazard accurately is used. In literature there are several studies on selection of real ground motion depending on the seismological characteristics of the site (Baker and Allin Cornell, 2006; Dhakal et al., 2007). The web based Pacific Earthquake Engineering Research Centre (PEER) seismic signal database for shallow crustal earthquakes in highly active tectonic regions is used for the unscaled real record. Database management system of PEER provides extensive data that considers the site characteristics, epicentre distance and properties of seismic excitation. Total of 3 real earthquake ground motion compatible with the target spectrum were downloaded. A comparison of selected ground motion and target spectrum is shown in Figure 9.

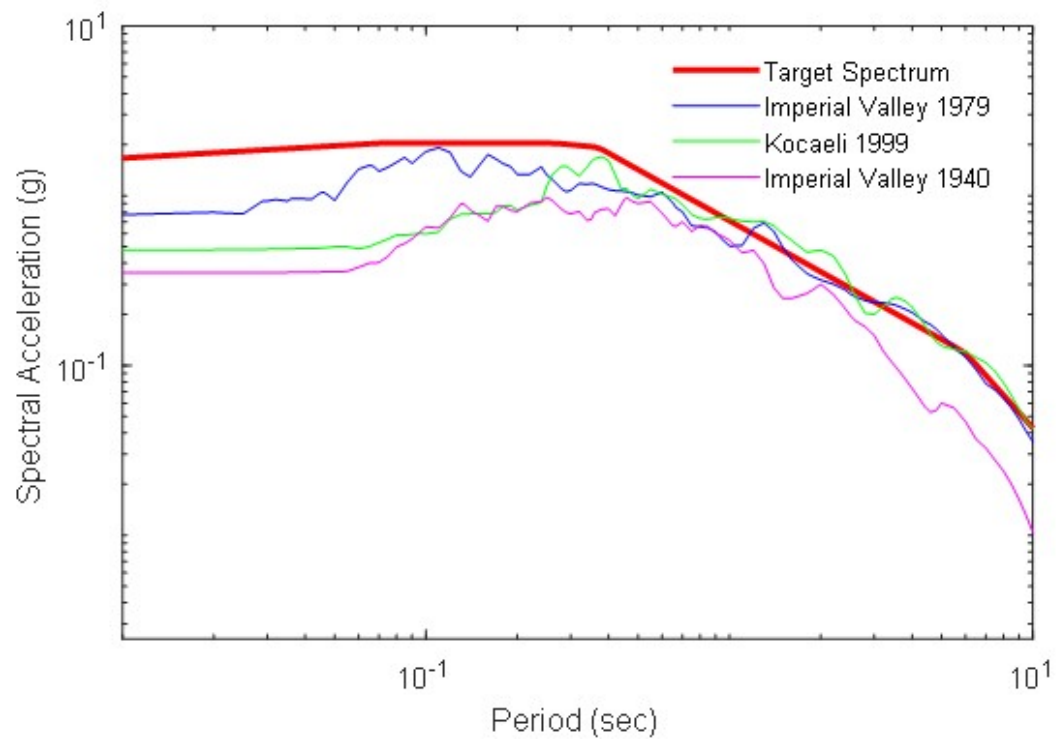

Figure 9 Comparison of selected ground motion and target spectrum.

\section{DISCRETE ELEMENT MODELLING}

In the framework of the computations, numerical modelling was performed by discrete elements created in the 3DEC software (Itasca, 2016). In the 3DEC, rigid stones were created by continuum elements whereas the unit mortar interface was represented by micro modeling approach. Mechanical properties adopted for the masonry clock tower were obtained from literature review that include experimental data conducted on masonry buildings and towers located in neighbouring region. It has been assumed that Elasticity modulus is $1.7 \mathrm{GPa}$, Poisson ratio is 0.2 -unit weight is $22 \mathrm{kN} / \mathrm{m} 3$. Due to the intrinsic behaviour of masonry buildings which is mostly nonlinear during seismic excitation discrete rigid blocks interacting through nonlinear interfaces were used. Normal and shear joint stiffness are determined using the geometrical properties of the rigid stones neighbouring to the joint. Shear stiffness is calculated using the ratio of the shear modulus to the average of the dimensions normal to the joint of the two blocks in contact. Normal stiffness at the interface is calculated using the ratio of the Young's modulus to the average of the dimensions normal to the joint of the two blocks in contact. In addition, Coulomb friction law was applied with the assumption of a friction angle of 30 degree. Firstly, eigen frequency analysis was conducted to evaluate the preliminary dynamic characteristics and behaviour of the masonry tower. In the 3DEC, relaxation solution algorithm was adopted to perform the static analysis under gravity loading. Eigen-frequency analysis allowed to identify the vibration modes and corresponding periods. As usually occurs for slender buildings, the masonry tower approximately responded like a cantilever beam that showed the consistently distribution of mass. Deformed shapes obtained from modal analysis corresponds to the five modes are shown in Figure 10. In these mode shapes colour patch represents the displacement magnitude distribution. It is clear from these figures that the first two modes are flexural and the third mode is torsional. In addition, it is not surprising that the largest excited mass in the direction of $X$ corresponds to the first mode and constitutes about $46 \%$ of the total mass, while the second mode corresponds to the direction of $Y$ and is around $45 \%$. As it was expected, structural response in two perpendicular direction were very close due to the quasi-square planar section of the masonry clock tower. Furthermore, eigen modes and the corresponding excited mass obtained from eigen-frequency analysis provided information to calculate the horizontal force distribution. 

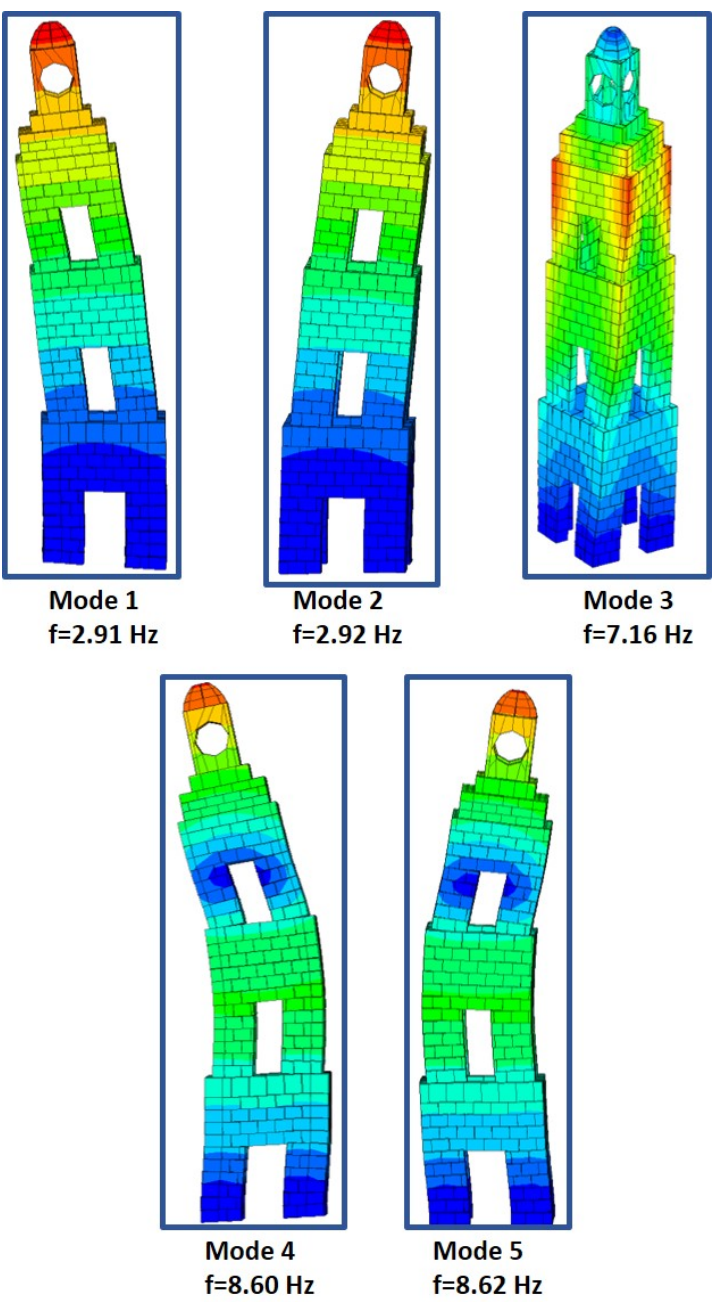

Figure 10 Mode shapes.

\section{NONLINEAR ANALYSIS}

Seismic behaviour of the Nusretiye Clock Tower was investigated through non-linear dynamic analyses. Here, the aim is to investigate the global structural response of the tower using real and artificial seismic loading that consistent with the earthquake hazard level, in accordance with the TBSC 2018. Seismic response assessment of existing masonry buildings is usually performed by linear or nonlinear analyses. In seismic evaluation guidelines, deformations are usually divided by some limits defining the performance levels of the member. FEMA 274 (1997), FEMA 356 (2000) and ASCE 4106 (2006) defines three limit states depend on drift ratio namely Immediate Occupancy, Life Safety and Collapse Prevention for primary members. The drift ratios for secondary walls are determined based on two performance level as Life safety and Collapse prevention. Eurocode 8 (EC8-3, 2005) has three limit states, as Near Collapse, Significant Damage and Damage Limitation For the approval requirements for in-plane walls for unreinforced masonry. Depending on the controlling failure mode Limit drift ratios in shear or flexure are calculated using the distance between the section where the flexural capacity is attained and the contra flexural point and in plane horizontal dimension of the wall. In TBSC 2018 Monumental structures are not clearly given. TBSC 2018 describes four performance limit states as Continuous Usage, Limited Damage, Controlled Damage and Collapse State. If the shear strength of all walls of the masonry building in both directions is sufficient to meet the shear forces generated under the applied earthquake effects, it is concluded that the building provides the Limited Damage performance level. If the contribution of the walls that do not meet this condition in the direction of the earthquake applied on any floor to the floor shear force is below $40 \%$, it will be accepted that the building provides the Controlled Damage performance level. If this ratio exceeds $40 \%$, the building is considered to be in the Collapse State.

The eigen-frequency analysis provided information to calculate the horizontal force distribution for static pushover analysis. The pushover analyses results showed that due to in-plane shear stresses, the masonry tower exhibits a failure mode driven by diagonal cracking along the wall of clock. Furthermore, the tower experienced the yielding at a 
displacement of about $9 \mathrm{~cm}$ and a lateral force of $2190 \mathrm{kN}$ corresponds to performance level of Controlled Damage give in TBSC 2018. Following the pushover analysis, nonlinear time history analysis was performed. During dynamic analysis recorded and artificial signals were applied as base excitation to the masonry tower. Artificial ground motions were created in one component. However, it is idea was the numerical model is subjected to seismic action in both orthogonal directions. Therefore, the 30 percent orthogonal loading rule is applied as $100 \%$ of the AGM is combined with $30 \%$ of the other AGM in both horizontal direction. In light of dynamic results, the trend is similar for each case of analysis that the maximum principal stresses were observed along the clock wall of the tower. As anticipated, cracks and openings appeared on the tower. A representative displacement magnitude distribution colour patch and local deformations under real ground motion are represented in Figure 11.

Under the all the artificial seismic loadings failure mechanisms were observed at the upper part of the tower and noticeable cracks and dislocation of blocks along the vertical dimension of the numerical model (Figure 12). Considerable residual displacements occurred under the real ground motion analysis resulted with inelastic deformation which would lead to failure mechanisms. Furthermore, local damages along the clock zone took place under these recorded excitations. In this region, at the end of the seismic excitations a residual displacement is about $10 \mathrm{~cm}$. Changing of maximum shear stress with the height of masonry tower under AGM and recorded strong ground motion (SGM) is plotted in Figure 13.
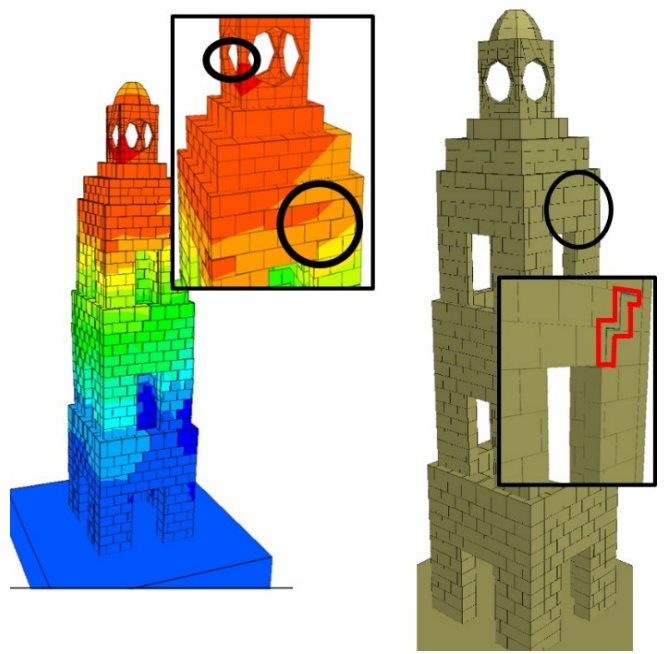

Figure 11 A representative displacement magnitude distribution colour patch and local deformations under real ground motion.

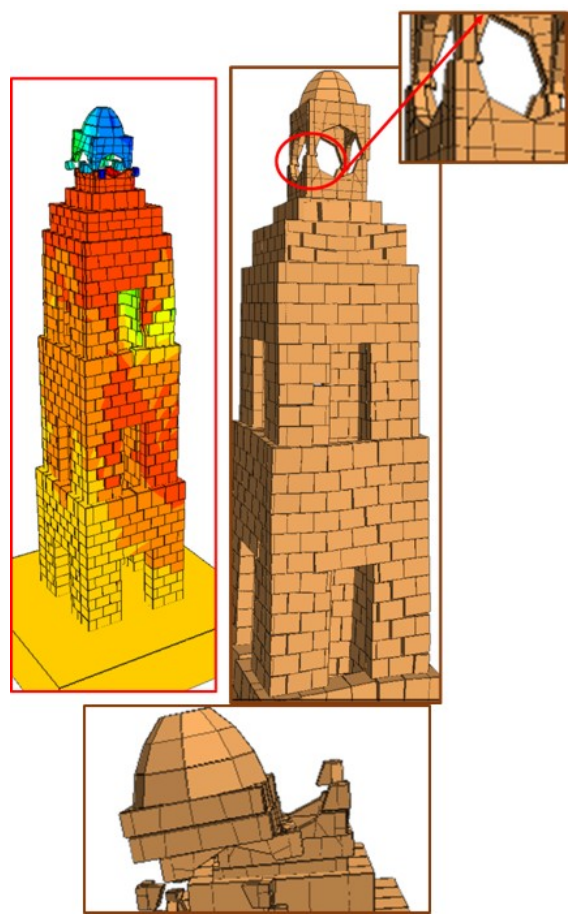

Figure12 Representative failure mechanisms under artificial ground motion. 


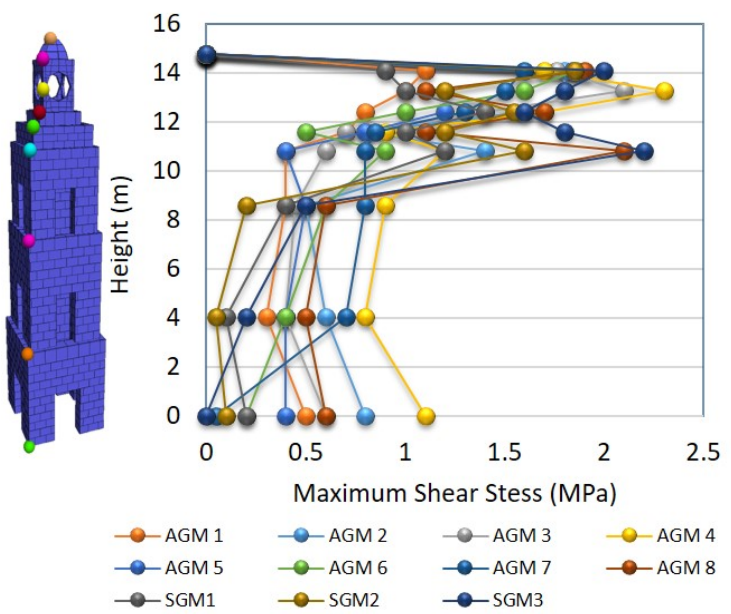

Figure 13 Changing of maximum shear stress with the height of masonry tower under AGM and SGM.

\section{RESULTS AND DISCUSSION}

In the study, the spatial variations of values were studied the means of earthquakes with a magnitude completeness of 2.8 in the Marmara region whose coordinate range is $26^{\circ}-31^{\circ} \mathrm{E}$ longitudes and $40^{\circ}-42^{\circ} \mathrm{N}$ latitudes, from $15 \mathrm{April} 1905$ to 31 December 2020. A complete set of 29223 earthquakes of Md $\geq 1$ was taken from the KOERI catalog (Figure 3a). The earthquakes occurred in the region between the years of 1970 and 2020 were particularly assessed within the scope of the study because the data set prior to 1970 was found insufficient due to lack of seismic records. For this analysis, number of the earthquake within the selected period was 23376 and magnitude range=1.09-7.4 and depth=0-50 km. A spatial grid of points with a distance of $0.05^{\circ}$ was assumed. With the Mc value assumed to be 2.8 , the b-value was then calculated as $1.48 \pm 0.02$. The distribution of $b$ value in the Marmara region varied extensively from 0.5 to 2.6 . On a local scale, the b-value varied from 0.3 to 2.5 or more was reported (e.g., Utsu, 1971). One of the previous studies carried out by Yeken (2016) indicated that the $b$ value in the Armutlu peninsula is not homogenous. The spatial analysis suggests that the b-values of seismicity for this region are not homogeneous. This suggests that this finding is common for the whole Marmara region. Also, the geological age of the tectonic structure of the studied region is consistent with the obtained finding from this study (Miyamura, 1962). The higher b-value in the vicinity of the city of İstanbul and the Istranca massif caused by the large heterogeneity (Tsapanos, 1990) is observed and is 2.5 . These findings seem consistent with the geologic properties of the Istanbul zone defined by a well-developed, unmetamorphosed, and little deformed continuous Paleozoic sedimentary succession extends from Ordovician to the Carboniferous overlain with a major unconformity by latest Permian to lowermost Triassic continental red beds (Okay, 1989). Also, we observed that the variations in the $b$-value of frequency-magnitude distribution of the earthquakes in the Marmara region indicate an increase in b-value with a depth of below $15 \mathrm{~km}$. This is probably related to Crustal heterogeneity (Mogi, 1962), thermal gradient and growing pore pressure (Wyss and Stefansson, 2006). Smaller b-values are observed in the Saros Gulf and the low pattern in the b-values were also observed in the Biga Peninsula and the Ganos Gulf. In addition to these, tectonic environment, data quality and completeness, magnitude type, depth and other geophysical and geotectonic characteristic influence variations in b-value.

The b-value of nearly 2.5 for the entire city of Istanbul and the Istranca massif (Figure 7) represents a largest value for this region value. This is probably relating to crustal heterogeneity of the region. The b-value of slightly greater than 0.5 for Ganos, the Ganos Gulf and the surrounding area represents a smaller value for this region. In addition, the bvalues for the southern part of the Marmara Sea, the city of Balikesir and the city of Bursa varied from 1 to smaller than 2. The b-values varied from 1 to 1.5 are also observed in the kocaeli Peninsula, the cities of Adapazarı, Düzce and Yalova, the Izmit Gulf and the Armutlu Peninsula where located in the Sakarya zone characterized by a variably metamorphosed and strongly deformed Triassic basement called the Karakaya Complex overlain with a major unconformity by Liassic conglomerates and sandstones which passes up to Middle Jurassic-Lower Cretaceous limestones and Upper Cretaceous flysch (Okay, 1989). Considering the findings provide to be established the correlation between the crustal areas with low $b$-values and the locations of the strongest earthquakes in the investigated region. The produced map of the $b$-value suggests that it may be helpful for estimating the location, depth, and maximal magnitude of the probable strong earthquakes in seismically active regions. Therefore, findings based on such a study can be used to assess seismic risks. 
In this paper, seismic response of the historical Nusretiye (Tophane) Clock Tower located in Turkey, is the subject of attention. To evaluate the vulnerability of the masonry building under input loadings; eigenvalue, pushover and nonlinear dynamic analyses have been applied. The eigenvalue analysis results conventionally represent dynamic characteristics of the tower that allowed to employ pushover simulation. For the purpose of simulating the collapse mechanism, the pushover analysis was carried out until a drop of the $25 \%$ of the base shear force. Later, the nonlinear dynamic analysis was performed aiming at detail numerical insights into tower seismic behaviour. When the results compared it is observed that the seismic demand displacement in pushover analyses is reasonably comparable with the maximum displacement observed from dynamic analysis. In the light of the results, clock tower is significantly vulnerable to suffer strong damage or collapse in earthquake with a return period of 2475 years. Under real and artificial loadings, the masonry tower exhibited poor performance with openings at mortar and dislocation of stone blocks. In addition, significant damages observed along the upper part of the tower in the area of the clock. Obviously, these results point out the adverse effects of the openings due to the clock. In the plane, the masonry tower is regular but irregular in elevation. Owing to the change in wall thickness and the presence of the clock cell, the tower presented a huge damages and seismic vulnerability. These deformations are more highlighted on the results of artificial ground motion data set. Finally, the 3DEC significantly has proving to be very useful and powerful to represent the failure mechanisms, sliding and dislocation of blocks to capture the actual behaviour in the nonlinear field.

\section{CONCLUSION}

All results based on the spatial analysis of the $b$-value obtained from the current catalog were listed as follows:

- The spatial analysis of this study suggests that the b-values of seismicity for this region are not homogeneous. This suggests that this finding is common for the whole Marmara region.

- The higher b-value in the vicinity of the city of istanbul and the Istranca massif caused by the large heterogeneity is observed and is 2.5 .

- The variations in the $b$-value of frequency-magnitude distribution of the earthquakes in the Marmara region indicate an increase in b-value with a depth of below $15 \mathrm{~km}$.

- Smaller b-values are observed in the Saros Gulf and the low pattern in the b-values also observed in the Biga Peninsula and the Ganos Gulf.

- The b-value of nearly 2.5 for the entire city of Istanbul and the Istranca massif represents a largest value for this region value.

- The b-value of slightly greater than 0.5 for Ganos, the Ganos Gulf and the surrounding area represents a smaller value for this region.

- The b-values for the southern part of the Marmara Sea, the city of Balikesir and the city of Bursa varied from 1 to smaller than 2.

- The b-values in the southern part of the Marmara Sea, the city of Balikesir and the city of Bursa varied from 1 to smaller than 2.

- The b-values varied from 1 to 1.5 are also observed in the kocaeli Peninsula, the cities of Adapazarı, Düzce and Yalova, the Izmit Gulf and the Armutlu Peninsula.

- In addition to the spatial analysis of the b-value, results obtained from the analysis of the vulnerability of the tower by using eigenvalue, pushover and nonlinear dynamic methods are listed as follows:

- The clock tower is significantly vulnerable to suffer strong damage or collapse in earthquake with a return period of 2475 years.

- Under real and artificial loadings, the masonry tower exhibited poor performance with openings at mortar and dislocation of stone blocks.

- Important damages observed along the upper part of the tower in the area of the clock.

- Obviously, these results point out the adverse effects of the openings due to the clock. In the plane, the masonry tower is regular but irregular in elevation. Owing to the change in wall thickness and the presence of the clock cell, the tower presented a huge damages and seismic vulnerability. These deformations are more highlighted on the results of artificial ground motion data set. 
- The 3DEC significantly has proving to be very useful and powerful to represent the failure mechanisms, sliding and dislocation of blocks to capture the actual behavior in the nonlinear field.

Author's Contribuitions: Conceptualization, Ö Saygılı; methodology, Ö Saygılı, G Polat; investigation, Ö Saygılı, G Polat; writing-original draft preparation, Ö Saygılı; writing-review and editing, Ö Saygılı, G Polat; visualization, Ö Saygılı, G Polat.

Editor: Marcílio Alves.

\section{References}

Acun, H. (1994). Anatolian Clock Tower, Ankara, in Turkish.

AFAD, (2020). Turkey Earthquake Hazard Maps Interactive Web Application, Disaster and Emergency Management Authority Presidential of Earthquake Department, https://tdth.afad.gov.tr/.

Aki, K. (1965). Maximum likelihood estimate of $b$ in the formula $\log (N)=a-b M$ and its confidence limits, Bull Earthq Res Inst Tokyo Univ. 43: 237-239.

Ambraseys, N., Finkel C. (1991). Long-term seismicity of Istanbul and of the Marmara Sea region, Terra Nova 3, pp. 527-539.

Ameri, G., Gallovic, F., Pacor, F. and Emolo. (2009). A Uncertainties in strong ground-motion prediction with finite-fault synthetic seismograms: An application to the 1984M 5.7 Gubbio, central Italy, earthquake", Bull Seismol Soc Am, 99(2A), 647663.

Armijo, R., Meyer, B., Hubert, A. and Barka, A.A. Westward Prop-agation of the North Anatolian Fault into the Northern Aegean: Timing and Kinematics, Geology, 27, 267-270, 1999.

ASCE 41-06 (2006). Seismic Rehabilitation of Existing Buildings, American Society of Civil Engineers, Reston, VA.

Baker, J.W., Allin Cornell, C. (2006). Spectral shape, epsilon and record selection, Earthquake Eng. Struct. Dyn., 35, pp. 10771095

Barka, A. A. (1992.) The North Anatolian Fault zone, Annales Tectonicae, Spec. Iss. VI, pp. 164-195.

Bohnhoff, M, Martınez-Garzon, P., Bulut, F., Stierle E., Ben-Zion, Y. (2016). Maximum earthquake magnitudes along different sections of the North Anatolian fault zone, Tectonophysics, 674, 147-165, https://doi.org/10.1016/j.tecto.2016.02.028.

Boore, D. M. (2003). Simulation of ground motion using the stochastic method, Seismic Motion, Lithospheric Structures, Earthquake and Volcanic Sources: The Keiiti Aki pp. 635-676.

BU-ARC (2002). Earthquake risk assessment for the Istanbul metropolitan area, Kandilli Observatory and Earthquake Research Institute, Istanbul.

Dhakal, R., Singh, S., and Mander, J. (2007). Effectiveness of earthquake selection and scaling procedure method in New Zealand, Bulletin of the New Zealand Society for Earthquake Engineering, 40(3), pp. 160-171.

European Committee for Standardization - EC8-3. (2005). European Standard EN 1998-3: 2005 Eurocode 8: Design of structures for earthquake resistance. Part 3: Assessment and retrofitting of buildings Brussels, Belgium.

FEMA 274 (1997). NEHRP Commentary on the Guidelines for the Seismic Rehabilitation of Buildings, Federal Emergency Management Agency (FEMA, Washington DC.

FEMA 356 (2000). Pre-standard and Commentary for the Seismic Rehabilitation of Buildings, Federal Emergency Management Agency (FEMA), Washington DC.

Frankel, A. (2009). A constant stress-drop model for producing broadband synthetic seismograms: Comparison with the Next Generation Attenuation relations, Bull Seismol Soc Am, 99(2A), pp. 664-680.

Giaralis, A., Spanos P.D. (2009). Wavelets based response spectrum compatible synthesis of accelerograms - Eurocode application (EC8), Soil Dyn Earthq Eng., 29, pp. 219-235. 
Graves, R.W., Pitarka A. (2004). Broadband time history simulation using a hybrid approach, Proc. 13th World Conf. on Earthq Eng, pp. 1-6.

Gürsu, L.T. (2016). Istanbul Nusretiye Clock Tower and conservation project in the context of the 19th century ottoman era clock towers, Msc. Thesis, Mimar Sinan Fine Arts University, Turkey.

Gutenberg B., Richter C.F. (1944). “Frequency of Earthquakes in California”, Bull. Seismol. Soc. Am., 34, 185-188.

Hancock, J., Watson-Lamprey, J., Abrahamson, N.A. (2006). An improved method of matching response spectra of recorded earthquake ground motion using wavelets J Earthq Eng., 10, 67-89.

IBB KUDEB (2011). Nusretiye Clock Tower Restoration and Conservation Report, in Turkish.

IMM (2009). İtanbul Olası Deprem Kayıpları, İstanbul Büyükşehir Belediyesi, in Turkish.

Irikura, K., Kagawa, T., and Sekiguchi, H. (1997). Revision of the empirical Green's function method by Irikura, 1986, Programme and Abstracts. Seismol. Soc. Japan, 2:B25.

Itasca (2016). 3DEC-Three-Dimensional distinct element code, Version 5.2; Minneapolis, USA.

Jackson, J. (1994). Active Tectonics of the Aegean Region. Annual Review of Earth and Planetary Sciences, vol. 22(1), pp. 239271.

JICA, IMM (2002). The study on a disaster prevention/mitigation basic plan in Istanbul including seismic microzonation in the Republic of Turkey, Pacific Consultants International, OYO Corporation, Istanbul.

Joshi A., Sandeep, K. (2014). Modelling of strong motion generation areas of the 2011 Tohoku, Japan earthquake using modified semi empirical technique, Natural Hazards, 71, pp. 587-609.

Kalafat, D. (2016). Statistical Evaluation of Turkey Earthquake Data (1900-2015): A Case study. Eastern Anatolian Journal of Science, 2 (1), 14-36. Retrieved from https://dergipark.org.tr/tr/pub/eajs/issue/24385/258511.

Kamae, K., Irikura, K. (1992). Prediction of site specific strong ground motion using semi-empirical methods, Proc. 10th World Conference on Earthquake Engineering, pp. 801-806.

Miyamura, S. (1962). Magnitude-frequency relations and its bearing to geotectonics. Proceeding of the Japan Academy, 38, 27-30.

Mogi, K. (1962). Magnitude-frequency relationship for elastic shocks accompanying fractures of various materials and some related problems in earthquakes. Bull. Earthquake Res. Inst. Univ. Tokyo, 40:831-883.

Motazedian, D., Atkinson, G.M. (2005). Stochastic finite-fault modeling based on a dynamic corner frequency, Bull Seismol Soc Am, 95(3), pp. 995-1010.

Okay, A.I. (1986). Tectonic units and sutures in the pontides, NorthernTurkey. Tectonic evolution of the Tethyan Region, NATO ASI Series, Series C-Vol., 259, 109-116.

Parsons, T. (2004). Recalculated probability of M7 earthquakes beneath the Sea of Marmara, Turkey, Journal of Geophysical Research Solid Earth, 109, https://doi.org/10.1029/2003JB002667 (ISSN 2156-2202).

Pichon, XL., Chamot-Rooke, N. and Lallemant, S. (1995). Geodetic Determination of the Kinematics of Central Greece with Respect to Europe: Implications for Eastern Mediterranean Tectonics. Journal of Geophysical Research, pp. 675690.

Polat, G., Saygılı, Ö. (2020). Structural evaluation for the preservation of an ancient Egyptian Obelisk in Istanbul, Turkey. Yerbilimleri, 41 (2), 169-182. DOI: 10.17824/yerbilimleri.630560.

Sarkar, K. Gupta, V., George, R. (2016). Wavelet-based generation of spatially correlated accelerograms, Soil Dyn Earthq Eng. 87, pp. 116-124.

Saroglu, F., Boray, A., and Emre, O.: Active faults of Turkey, Dis-sertation, Mineral Research and Exploration Institute of Turkey,1987.

Scholz, C.H. (1968). The frequency-magnitude relation of microfracturing in rock and its relation to earthquakes. Bull. Seismol. Soc. Am., 58: 399-415.

Şengör, AMC (2005). The North Anatolian Fault: A new look, Annu. Rev. Earth Planet. Sci., 33, 37-112. 
Suárez, L.E, Montejo, LA. (2005). Generation of artificial earthquakes via the wavelet transform, Int J Solids Struct., 42, pp 5905-5919.

TBSC 2018, Turkish Building Seismic Code 2018, Prime Ministry, Disaster and Emergency Management Presidency (AFAD), Ankara, 2018.

Tsapanos, T.M. (1990). b-Values of two tectonic parts in the circum-pacific belt. PAGEOPH 134, 229-242. https://doi.org/10.1007/BF00876999.

Urbancic, T.I., Trifu, C.I., Long, J.M. and Young, R.P. (1992). Space-time correlations of b values with stress release. Pure and Applied Geophysics,139(3-4), 449-462.

Utsu, T. (1971). Seismological evidence for anomalous structure of island arcs with special reference to the Japanese region. Re-views of Geophysics, 9(4), 839-890.

Vanmarcke, E.H., Gasparini, D.A. (1977). Simulated earthquake ground motions, Paper presented at: Proceedings of the 4th InternationalConference on SMIRT, K1/9, San Francisco, CA.

Warren, N.W. and Latham, G.V. (1970). An experimental study of thermally induced microfracturing and its relation to volcanic seismicity. J. Geophys. Res., 75, 4455-4464.

Wiemer, S. (2001). A software package to analyze seismicity: ZMAP. Seismol. Res. Lett. 72, p.373-382

Wiens, D.A. and Gilbert, H.J. (1996). Effect of slab temperature deep earthquake aftershock productivity and magnitudefrequency relations, Nature, 384, 153-156, 1996.

Wollin, C., Bohnhoff, M., Vavryčuk, V. (2019). Stress inversion of regional seismicity in the Sea of Marmara Region, Turkey, Pure Appl. Geophys. 176, pp. 1269-1291.

Wyss, M. (1973). Towards a physical understanding of the earthquake frequency distribution, Geophys. J. R. Astron. Soc., 31, 341-359.

Wyss, M., Stefansson, R. (2006). Nucleation points of recent mainshocks in southern Iceland, mapped by b-values. Bulletin of the Seismological Society of America, 96, pp. 599-608.

Yamamoto, Y., Baker, J.W. (2013). Stochastic model for earthquake ground motion using wavelet packets, Bull Seismol Soc Am, 103(6), pp. 3044-3056.

Yeken, T. (2016). Spatial Analysis of b-value Variability in Armutlu Peninsula (NW Turkey), Open Geosciences, vol. 8, no. 1, pp. 548-555. https://doi.org/10.1515/geo-2016-0048

Yu, G., Khattri, K.N., Anderson, J.G., Brune, J.N., Zeng, Y. (1995). Strong ground motion from the Uttarkashi, Himalaya, India, earthquake: Comparison of observations with synthetics using the composite source model, Bull. Seism. Soc. Amer., 85, pp. 31-50. 